\title{
EVALUASI PROGRAM MAHASISWA WIRAUSAHA UNIVERSITAS NEGERI PADANG
}

\section{Tri Hutari, Asmar Yulastri, Yuliana}

Abstrak: Penelitian ini bertujuan untuk mengevaluasi komponen konteks, masukan, proses, dan hasil pada Program Mahasiswa Wirausaha di Universitas Negeri Padang. Jenis penelitian adalah penelitian evaluasi dengan model evaluasi CIPP (Context, Input, Process, Product). Metode yang digunakan yaitu Mixed Method dengan pendekatan kuantitatif dan kualitatif secara urutan pembuktian (sequential explanatory). Penelitian ini dicirikan dengan pengumpulan data dan analisis kuantitatif pada tahap pertama dan diikuti dengan pengumpulan dan analisis kualitatif pada tahap kedua untuk memperkuat hasil temuan pada pendekatan kuantitatif. Hasil yang diperoleh dari penelitian ini dapat disimpulkan bahwa komponen konteks, masukan, proses dan hasil pada Program Mahasiswa Wirausaha di Universitas Negeri Padang berada pada kategori kurang memuaskan. Komponen masukan, komponen proses dan komponen hasil perlu diperbaiki supaya Program Mahasiswa Wirausaha dapat dilaksanakan secara optimal. Berdasarkan temuan penelitian dapat direkomendasikan Program Mahasiswa Wirausaha dapat dilanjutkan dengan melakukan perbaikan pada setiap komponennya.

Kata kunci:Evaluasi Program, Model CIPP, Metode Kombinasi, Program Mahasiswa Wirausaha

Abstract:This research aimed to evaluate the component of context, input, process, and product on Entrepreneurship Program at Universitas Negeri Padang. This research was an evaluate study with CIPP model (Context, Input, Process, Product). The method was used a mixed method with quantitative and qualitative approach by sequential explanatory. This research was characterized by collected and analyzed quantitative data at first stage and qualitative data at second stage to reinforce the result of quantitative approach. The result of this research showed that the component of the context, input, process, and product on Entrepreneurship Program at Universitas Negeri Padang was at less satisfactory category. The component of input, process and product should be improved to make The Entrepreneurship Program to be more optimal. The recommended is The Entrepreneurship Program can proceed with the improvement at each of its components.

Keywords: Evaluation Program, CIPP Model, Mixed Method, Entrepreneurship Program

\section{A. Pendahuluan}

Permasalahan pengangguran merupakan permasalahan nasional yang perlu dipecahkan secara terpadu dan sinergi oleh dinas, lembaga terkait dan komponen masyarakat yang peduli. Dilihat dari latar belakang pendidikan berdasarkan data pada Tabel 1.1 menunjukkan jumlah pengangguran terbuka dengan latar belakang pendidikan universitas mengalami kenaikan. 


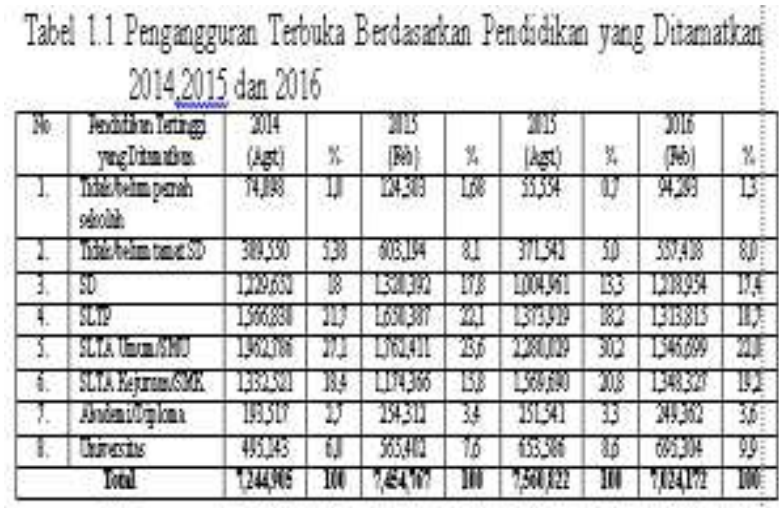

Salah satu faktor penyebab meningkatnya jumlah pengangguran lulusan Perguruan Tinggi di Indonesia yaitu sebagian besar lulusan Perguruan Tinggi cenderung lebih sebagai pencari kerja (job seeker) daripada pencipta lapangan pekerjaan (job creator).

Direktorat Jenderal Pendidikan Tinggi Kemenristekdikti merealisasikan berbagai kebijakan dan program pengembangan budaya kewirausahaan di Perguruan Tinggi. Hal ini dilakukan untuk menumbuhkembangkan jiwa kewirausahan dan meningkatkan aktivitas kewirausahaan agar para lulusan perguruan tinggi lebih menjadi pencipta lapangan kerja. Salah satu program yang telah dikembangkan adalah Program Mahasiswa Wirausaha (PMW). Program ini telah diselenggarakan di Universitas Negeri Padang sejak tahun 2009. Mahasiswa yang mempunyai minat dan bakat dibimbing dan dibina dengan baik untuk melanjutkan kreativitas mereka. Sumber dana yang digunakan oleh Universitas Negeri Padang dalam program ini bersumber dari Direktorat Jenderal Pendidikan Tinggi (DIKTI).

Pelaksanaan Program Mahasiswa Wirausaha (PMW) melibatkan mahasiswa secara langsung untuk memulai unit usaha yang mereka inginkan melalui seleksi, pengawasan dan evaluasi dari pendamping usaha. Pada akhirnya, apabila PMW berjalan dengan baik mahasiswa mampu menjadi pengusaha muda dengan peluang bisnis-bisnis baru dan mampu memberikan dukungan terhadap kehendak pemerintah dalam mewujudkan kemandirian bangsa melalui penciptaan lapangan kerja dan pemberdayaan Usaha Kecil dan Menengah (UKM). Proses pelaksanaan PMW di Universitas Negeri Padang dapat dilihat dari Gambar 1.

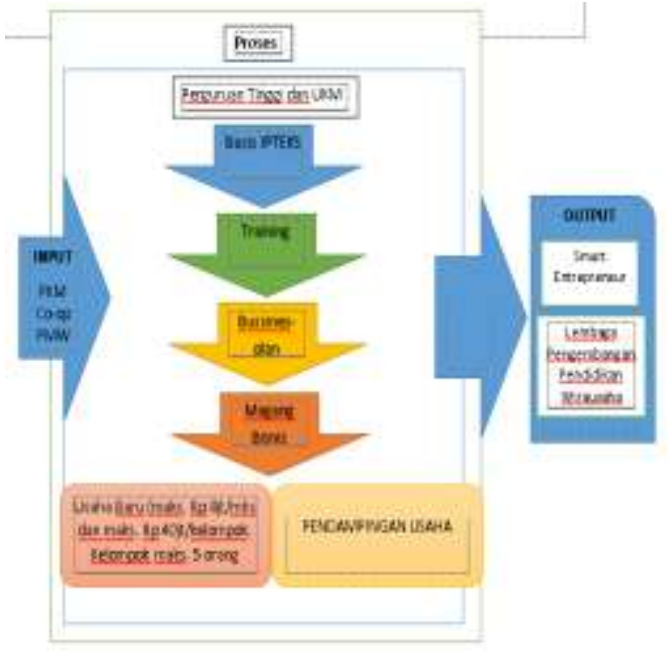

Gambar 1. Proses Pelaksanaan Program Mahasiswa Wirausaha di Universitas Negeri Padang. 
Berdasarkan dari observasi awal yang dilakukan penulis pada bulan oktober 2016, dalam pelaksanaan Program Mahasiswa Wirausaha banyak unit usaha peserta yang terhenti. Dilihat dari Tabel 1.2 dari tahun 2014 yang mendapatkan pendanaan berjumlah 22 kelompok, namun hanya 4 kelompok yang dapat melanjutkan usaha hingga sekarang. Begitu juga dengan pendanaan tahun 2015 berjumlah 52 kelompok, namun hanya 6 kelompok yang dapat melanjutkan usaha hingga sekarang. Program ini mengalami penurunan di mana jiwa kewirausahaan yang dimiliki mahasiswa semakin menurun, namun jumlah mahasiswa yang mengikuti program tersebut meningkat dari tahun ke tahun.

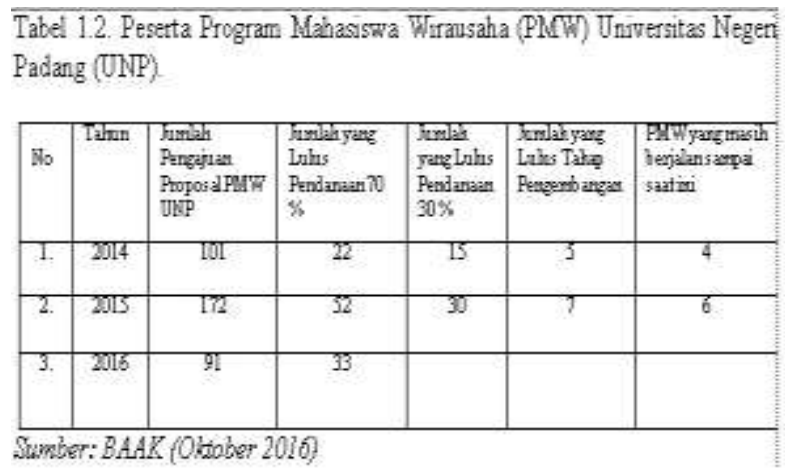

PMW memiliki beberapa indikator keberhasilan program yaitu Jumlah Mahasiswa yang berhasil menjalankan usaha (sebagai wirausaha), terbentuknya model pendidikan kewirausahaan di perguruan tinggi dan terbentuknya lembaga pengembangan pendidikan kewirausahaan yang mengkoordinasikan berbagai kegiatan terkait dengan kewirausahaan di perguruan tinggi (Kemenristekdikti, 2015:20).

Berdasarkan hasil wawancara yang dilakukan pada bulan Oktober 2016 terhadap peserta PMW Universitas Negeri Padang terdapat beberapa masalah atau faktor penghambat lainnya yang ditemui yaitu mahasiswa tidak melakukan praktek magang sesuai dengan waktu yang telah ditentukan dan hanya mengabadikan dokumentasi pada tempat magangnya. Selanjutnya, adanya perbedaan antara pengetahuan (teori) yang diperoleh di lembaga pendidikan dan ketidakseriusan mahasiswa pada saat pembekalan materi Kewirausahaan dengan yang ditemukan di lapangan, menjadikan faktor penghambat dari pelaksanaan PMW.

Permasalahan berikutnya ditemukan pada mahasiswa yang sedang melaksanakan PMW, mahasiswa menghasilkan produk usaha yang kurang bervariasi. Hal ini akan mengakibatkan usaha tidak berjalan untuk jangka waktu lama. Selain itu ditemukan mahasiswa yang masih kurang dalam manajemen waktu dan kerjasama antar sesama peserta di dalam kelompok.

Melihat hal tersebut penulis merasa perlu diadakan evaluasi terhadap Program Mahasiswa Wirausaha di Universitas Negeri Padang. Adapun tujuan penelitian evaluasi ini sesuai dengan pendapat Suharsimi dan Cepi (2010:18) mengatakan bahwa, "Evaluasi program adalah upaya untuk mengetahui tingkat keterlaksanaan suatu kebijakan secara cermat dengan cara mengetahui efektifitas masing-masing komponen".Evaluasi ini diharapkan bisa menghasilkan hal-hal yang perlu dibenahi dalam PMW di Universitas Negeri Padang. Apabila suatu program tidak dievaluasi maka tidak dapat diketahui bagaimana dan seberapa baik kebijakan yang sudah dikeluarkan dapat terlaksana.

Selain itu, evaluasi Program Mahasiswa Wirausaha ini penting dilaksanakan karena belum pernah dilakukan penelitian tentang evaluasi PMW di Universitas Negeri 
Padang. Evaluasi program merupakan suatu proses sistematis untuk mengumpulkan, menganalisis, dan memakai informasi untuk menjawab pertanyaan dasar mengenai program (Wirawan, 2011:17). Evaluasi program ini bertujuan untuk mengevaluasi sejauh mana PMW telah dilaksanakan dan hambatan apa saja yang ditemui selama proses pelaksanaanya.

\section{B. Landasan Teori}

\section{A. Evaluasi Program}

Evaluasi adalah kegiatan untuk mengumpulkan informasi tentang bekerjanya sesuatu yang selanjutnya informasi tersebut digunakan untuk menentukan alternatif yang tepat dalam mengambil keputusan (Arikunto dan Jabar, 2010:2). Evaluasi menurut Undang-undang Republik Indonesia Nomor 2 tahun 2003 tentang Sisdiknas pasal 57 ayat (1) menyatakan bahwa evaluasi dilakukan dalam rangka pengendalian mutu pendidikan secara nasional sebagai bentuk akuntabilitas penyelenggara pendidikan kepada pihak-pihak yang berkepentingan diantaranya terhadap peserta didik, lembaga dan program pendidikan.

Selanjutnya Cross dalam Sukardi (2011:1) mendefinisikan bahwa "Evaluation is a process which determines the extent to which objectives have been achieved. Evaluasi merupakan proses yang menentukan kondisi dimana suatu tujuan telah dapat dicapai". Wirawan (2011:7) menyatakan bahwa "evaluasi sebagai riset untuk mengumpulkan, menganalisis dan menyajikan informasi yang bermanfaat mengenai objek evaluasi, menilainya dengan membandingkannya dengan indikator evaluasi dan hasilnya dipergunakan untuk mengambil keputusan mengenai keputusan mengenai objek evaluasi".

Berdasarkan teori-teori mengenai evaluasi yang telah dikemukakan tersebut, bahwa evaluasi adalah suatu proses atau kegiatan memilih, mengumpulkan, menganalisis dan menyajikan informasi yang dapat digunakan sebagai dasar pengambilan suatu kebijakan atau keputusan mengenai suatu objek.

Salah satu objek dalam evaluasi adalah program. Istilah program secara umum dapat diartikan sebagai suatu "rencana". Program adalah suatu rencana yang melibatkan berbagai unit yang berisi kebijakan dan rangkaian kegiatan yang harus dilakukan dalam kurun waktu tertentu. Program menurut Arikunto dan Jabar (2010:4) adalah "Suatu unit atau kesatuan kegiatan, maka sebuah program merupakan suatu sistem yaitu rangkaian kegiatan yang dilakukan bukan hanya satu kali tetapi berkesinambungan".

Berdasarkan uraian mengenai istilah evaluasi dan program di atas dapat dimengerti bahwa evaluasi program adalah penerapan prosedur ilmiah yang sistematis untuk menilai rancangan, selanjutnya menyajikan informasi dalam rangka pengambilan keputusan terhadap implementasi dan efektifitas suatu sistem yang terencana dan berkesinambungan (program).

\section{B. Program Mahasiswa Wirausaha}

Menurut Kementrian Ristek dan Dikti (2015: 6) Program Mahasiswa Wirausaha merupakan salah satu program dalam sistem pembelajaran/ pendidikan di perguruan tinggi. Dengan demikian, PMW harus terintegrasi dan disinergikan dengan programprogram kewirausahaan yang telah ada seperti; Kuliah Kewirausahaan, Program Kreativitas Mahasiswa Kewirausahaan (PKMK), Program Magang/ Belajar Bekerja Terpadu/ Co-op, Kuliah Kerja Usaha (KKU) dan program kewirausahaan lainnya. 
Program Mahasiswa Wirausaha juga merupakan sebuah kebijakan yang dikeluarkan oleh pemerintah yang juga merupakan program prioritas Dikti yang didelegasikan kepada perguruan tinggi. Oleh karena itu, bisa saja lain unversitas lain aturan karena adanya peranan dari otonomi kampus dalam pelaksanaan Program Mahasiswa Wirausaha. Program ini dilatarbelakangi karena banyaknya angka pengangguran terdidik. Tingginya angka pengangguran terdidik dikarenakan semakin sempitnya lapangan pekerjaan yang tersedia. Selain itu juga dikarenakan sebagian besar lulusan perguruan tinggi lebih cenderung sebagai pencari kerja bukan pencipta lapangan pekerjaan. Dengan adanya PMW maka diharapkan para mahasiswa mampu berwirausaha dan bahkan mungkin dapat menyediakan lapangan usaha untuk orang disekitarnya.

Program ini diharapkan mampu mendukung visi-misi pemerintah dalam mewujudkan kemandirian bangsa melalui penciptaan lapangan kerja dan pemberdayaan Usaha Kecil Menengah (UKM) serta mampu mengurangi angka pengangguran terdidik di Indonesia. Selain itu, dengan adanya PMW juga diharapkan akan semakin banyak generasi muda yang tertarik untuk menjadi entrepreneur dan bisa membangkitkan lagi perekonomian Indonesia.

\section{Penelitian Relevan}

Beberapa penelitian yang relevan tentang evaluasi terhadap Program Mahasiswa Wirausaha, yaitu:

1. Andi Taufiq (2012) dengan judul Evaluasi Program Mahasiswa Wirausaha Di Universitas Hasanuddin, menemukan bahwa model evaluasi program yang digunakan adalah CIPP model dan menggunakan metode campuran (Mixed Methods). Hasilnya penelitian menunjukkan pada keseluruhan indikator keberhasilan yang ditetapkan oleh Dikti, maka terlihat bahwa tingkat pencapaiannya sangat rendah dan dapat dikatakan bahwa program ini tidak berhasil. Namun demikian kami tidak menyarankan agar PMW ini dihentikan mengingat tujuan dan fungsinya sangatlah strategis dalam mendorong kemajuan bangsa. Penelitian menemukan bahwa ketidakberhasilan program bukan karena kekurangan dalam hal implementasi program tapi ketidaksesuaian model dari PMW itu sendiri dalam mencapai hasil yang diinginkan sehingga perlu dikembangkan model baru.

2. Putu Desta Sativana (2014) dengan judul Tingkat Keberhasilan Program Mahasiswa Wirausaha (PMW) di Undiksha ditinjau dari aspek unit bisnis. Hasil penelitian menunjukkan bahwa 1) tingkat keberhasilan PMW di Undiksha ditinjau dari aspek unit bisnis tahun 2012 secara keseluruhan memiliki pesentase sebesar 35\% termasuk dalam kategori tidak berhasil, 2) masalah yang dihadapi mahasiswa PMW dalam menjalankan unit bisnis tahun 2012 yaitu arus kas tidak lancar, sulit mengkoordinasi antar anggota PMW dalam mengelola usaha, omset tidak memenuhi target, modal tidak mencukupi, persediaan barang tidak stabil, dan 3) cara mengatasi masalah yang dihadapi mahasiswa PMW tahun 2012 yaitu menawarkan harga produk yang lebih terjangkau, bekerjasama dengan partner, membentuk sistem kerja yang efektif, mempekerjakan karyawan, meningkatkan intensitas promosi, menghimpun modal dari modal pribadi atau pinjaman rekan kerja, dan menyesuaikan persediaan barang dengan permintaan konsumen. 


\section{Metode}

\section{A. Jenis Penelitian}

Jenis penelitian ini adalah penelitian evaluasi dengan model Context, Input, Process, Product (CIPP). Dalam hal ini peneliti mengevaluasi Program Mahasiswa Wirausaha di Universitas Negeri Padang yang ditinjau dari (a) Context, (b) Input, (c) Process, dan (d) Product. Metode yang digunakan dalam penelitian ini adalah Mixed Method dengan pendekatan kuantitatif dan kualitatif secara urutan pembuktian (sequential explanatory). Pendekatan kuantitatif pada penelitian ini menggunakan angka pengolahan statistik dan pendekatan kualitatif untuk mengungkap fenomena yang terjadi dan diangkat dari fakta-fakta secara wajar, bukan dari kondisi yang terkendali atau manipulasi. Untuk menguatkan deskripsi data kuantitatif digunakan data kualitatif yang didapatkan dari hasil dokumentasi, wawancara, maupun observasi kepada subjek penelitian. Subjek Penelitian nya yaitu peserta Program Mahasiswa Wirausaha tahun 2016.

\section{B. Prosedur Penelitian}

Prosedur penelitian merupakan alur kegiatan penelitian yang akan dilaksanakan selama proses penelitian. Berikut prosedur penelitian dalam penelitian ini.

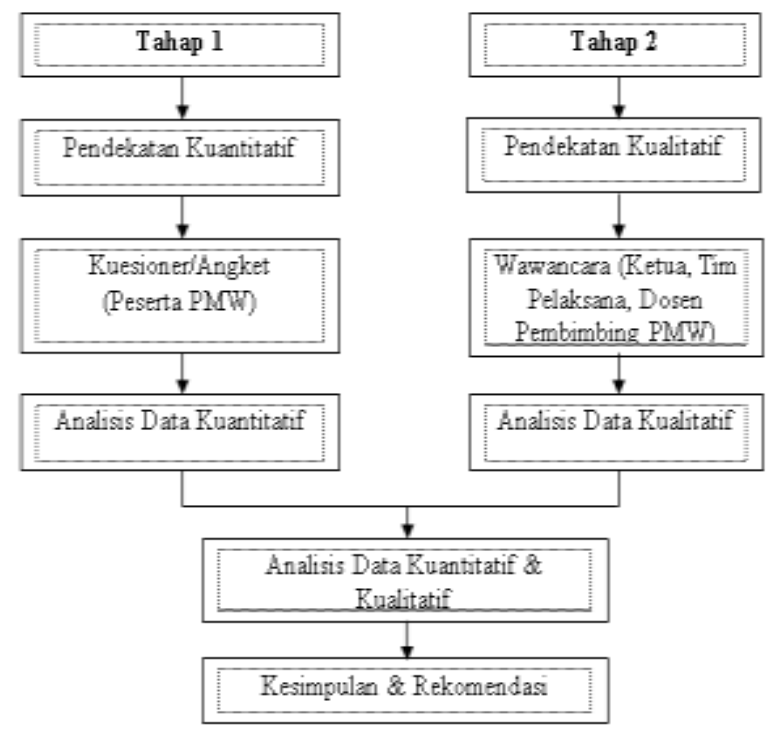

Gambar 3. Prosedur Penelitian

Berdasarkan Gambar 3. dapat dijelaskan bahwa penelitian ini menggunakan dua pendekatan, yaitu pendekatan kuantitatif dan pendekatan kualitatif. Dimana pendekatan kualitatif digunakan sebagai pelengkap atau sebagai tambahan informasi dari pendekatan kuantitatif. Instrumen yang digunakan dalam pendekatan kuantitatif adalah kuesioner (angket). Angket diberikan kepada peserta PMW. Setelah penyebaran instrumen dilakukan kemudian analisis terhadap data yang diperoleh guna untuk mengetahui tingkat pencapaian responden pada masing-masing indikator.

Langkah selanjutnya hasil dari analisis data pada pendekatan kuantitatif maka selanjutnya dilakukan pendekatan kualitatif. Pendekatan kualitatif dilakukan dengan melakukan wawancara. Wawancara dilakukan dengan Ketua PMW, Tim Pelaksana PMW, dan Dosen Pembimbing PMW di Universitas Negeri Padang. Hasil wawancara kemudian dianalisis guna sebagai pelengkap dari data kuantitatif. Hasil analisis data kuantitatif dan kualitatif dianalisis secara bersama-sama. Hal ini dilakukan untuk pengambilan kesimpulan dan rekomendasi dari masing-masing indikator. 


\section{Hasil dan Pembahasan}

\section{Komponen Konteks}

Komponen konteks dalam Program Mahasiswa Wirausaha di Universitas Negeri Padang indikator yang ditinjau dari tujuan Program Mahasiswa Wirausaha. Berdasarkan angket yang disebarkan kepada 33 orang peserta dengan 30 butir pernyataan, diperoleh hasil untuk indikator tujuan sebesar 3,72 dengan tingkat pencapaian sebesar 74,41\% dan termasuk ke dalam kategori cukup. Artinya tujuan dari Program Mahasiswa Wirausaha di Universitas Negeri Padang belum maksimal terwujud dengan baik. Namun, peserta sudah mulai berani menumbuh kembangkan pola pikir pencipta lapangan kerja dengan memulai bisnis walaupun belum optimal dan masih banyak yang terhenti usahanya. Selanjutnya, telah mendorong pertumbuhan, perkembangan atau terbentuknya kelembagaan (unit/ pusat) pengelola program kewirausahaan di perguruan tinggi dan telah mendorong terbentuknya model pendidikan atau pembelajaran kewirausahaan di perguruan tinggi meskipun belum semua tujuan tercapai secara maksimal.

Hasil wawancara mengenai tujuan Program Mahasiswa Wirausaha dapat disimpulkan bahwa Program Mahasiswa Wirausaha memiliki tujuan yang baik untuk membentuk softskill atau karakter wirausaha dan menciptakan pola pikir pencipta lapangan kerja. Tujuan tersebut yaitu untuk menanamkan karakter wirausaha tersebut agar peserta memiliki jiwa wirausaha yang bisa digunakan untuk menciptakan lapangan pekerjaan setelah menyelesaikan masa kuliah nya di universitas. Namun, tujuan program mahasiswa wirausaha ini belum tercapai dengan baik sebagaimana hendaknya yaitu supaya peserta memiliki softskill atau karakter wirausaha dan bisa menumbuh kembangkan pola pikir pencipta lapangan kerja. Hal ini berkenaan dengan tujuan Program Mahasiswa Wirausaha yang dijelaskan oleh Kementrian Ristek dan Dikti pada buku pedoman Program Mahasiswa Wirausaha (2015:5) yaitu (1) Membangun softskill atau karakter wirausaha, (2) Menumbuh kembangkan wirausahawirausaha baru yang berpendidikan tinggi dan memiliki pola pikir pencipta lapangan kerja, (3) Mendorong pertumbuhan, perkembangan atau terbentuknya kelembagaan (unit/pusat) pengelola program kewirausahaan di perguruan tinggi, dan (4) Mendorong terbentuknya model pendidikan atau pembelajaran kewirausahaan di perguruan tinggi.

2. Komponen Masukan

Komponen masukan dalam Program Mahasiswa Wirausaha terbagi dalam dua indikator yang ditinjau dari sumber daya manusia (peserta) dan pendanaan. Berdasarkan angket indikator sumber daya manusia (peserta) yang disebarkan kepada 33 orang peserta dengan 31 butir pernyataan, diperoleh hasil untuk indikator sebesar 3,96 dengan tingkat pencapaian sebesar 79,15\% dan termasuk ke dalam kategori cukup. Artinya Sumber daya manusia (peserta) telah memiliki minat dan motivasi berwirausaha yang baik. Namun, sumber daya manusia (peserta) masih kurang pada kesiapannya untuk pelaksanaan dalam berwirausaha. Hal ini akan mengakibatkan peserta tidak bertahan lama untuk menjalankan usaha yang dikelola. Apabila kesiapan peserta untuk berwirausaha telah dilatih dan dioptimalkan, maka akan terbentuk lah sumber daya manusia (peserta) Program Mahasiswa Wirausaha yang mampu menciptakan lapangan kerja dan memberdayakan orang-orang disekitarnya.

Berdasarkan angket indikator pendanaan yang disebarkan kepada 33 orang peserta dengan 2 butir pernyataan, diperoleh hasil untuk indikator pendanaan sebesar 84,85\% dan termasuk ke dalam kategori baik. Artinya, Universitas telah mendukung penuh 
Program Mahasiswa Wirausaha ini agar berjalan dengan baik dengan memberikan dana bantuan modal untuk start-up business. Peserta menerima pendanaan yang diberikan universitas untuk dukungan modal dalam menciptakan usaha nya.

Hasil wawancara mengenai sumber daya manusia (peserta) dalam Program Mahasiswa Wirausaha dapat disimpulkan bahwa sumber daya manusia (peserta) masih cukup kurang baik untuk menjalankan usaha yang dikelolanya. Hal ini terlihat pada sub indikator kesiapan mahasiswa untuk berwirausaha yang dimiliki oleh peserta Program Mahasiswa Wirausaha yang belum maksimal yang akan mengakibatkan peserta tidak bertahan lama untuk menjalankan usaha dikelola.

Berkenaan dengan persyaratan bagi mahasiswa untuk Program Mahasiswa Wirausaha yang dijelaskan oleh Kementrian Ristek dan Dikti pada buku pedoman Program Mahasiswa Wirausaha (2015:7), yang menyatakan bahwa 1) Program ini dapat diikuti oleh mahasiswa S1 Universitas/Institut/ Sekolah Tinggi dan diploma/ politeknik yang terdaftar di PD-Dikti dan telah menyelesaikan kuliah 2 semester atau minimal telah menyelesaikan 36 SKS. 2) Mahasiswa yang telah memenuhi syarat diharapkan menempuh seleksi yang meliputi aspek minat, motivasi berwirausaha, kelayakan usaha dan soft skills. Seleksi dilakukan oleh tim profesional yang terdiri dari unsur perguruan tinggi, pengusaha, dan perbankan. Keterlibatan pihak-pihak tersebut penting mengingat mahasiswa harus didampingi oleh mentor dari perguruan tinggi yang terlibat langsung dalam proses pendidikan kewirausahaan, sedangkan UKM merupakan tempat magang dan yang mempunyai pengalaman praktis berusaha, dan perbankan merupakan pihak yang terkait serta berpengalaman dalam hal kelayakan finansial. 3) Mahasiswa bersedia mengikuti peraturan dan tata tertib pengelola program PMW dengan mengikuti seluruh tahapan yang dijadwalkan, kemudian setelah menerima bantuan dana secara regular memberikan laporan pertanggungjawaban perkembangan usahanya kepada pengelola.

Hasil wawancara mengenai pendaaan dalam Program Mahasiswa Wirausaha dapat disimpulkan bahwa sudah berjalan dengan baik. Pendanaan disini bersifat dana hibah yang diberikan untuk membantu start-up bisnis yang dikelola oleh peserta. Agar usaha yang dikelola berjalan dengan lancar, peserta dituntut harus bisa mengelola manajemen keuangan yang baik. Berkenaan dengan pendanaan untuk Program Mahasiswa Wirausaha yang dijelaskan oleh Kementrian Ristek dan Dikti pada buku pedoman Program Mahasiswa Wirausaha (2015:6) point 7 dan 8 yang menyatakan bahwa 1) Pendirian usaha baru dapat dilakukan secara perorangan (individu) atau secara berkelompok. Jumlah modal usaha yang disediakan untuk pendirian usaha maksimal Rp8.000.000,00 (delapan juta rupiah) per mahasiswa. Apabila berkelompok maka jumlah anggota maksimal 5 (lima) orang dengan jumlah modal usaha maksimal Rp40.000.000,00 (empat puluh juta rupiah). 2) Modal usaha juga dimungkinkan untuk pengembangan usaha yang sedang berjalan dengan pengaturan khusus oleh perguruan tinggi.

Berdasarkan penjelasan di atas dapat disimpulkan bahwa suatu program membutuhkan masukan yang baik terkait unsur dalam Program Mahasiswa Wirausaha. Komponen masukan yang telah dievaluasi dan memperoleh hasil cukup, perlu dilakukan perbaikan dan pengoptimalan di setiap unsur komponennya.

\section{Komponen Proses}

Komponen proses dalam Program Mahasiswa Wirausaha terbagi dalam tiga indikator yang ditinjau dari mekanisme, hambatan dan solusi dari hambatan. Berdasarkan angket yang disebarkan kepada 33 orang peserta dengan 30 butir pernyataan, diperoleh hasil untuk indikator mekanisme sebesar 0,77 dengan tingkat E-ISSN: 2657-0300 Lembaga Penelitian dan Penerbitan Hasil Penelitian Ensiklopedia 
pencapaian sebesar $77,41 \%$ dan termasuk ke dalam kategori cukup. Artinya mekanisme tergolong kategori cukup. Mekanisme program mahasiswa wirausha di Universitas Negeri Padang cukup berjalan sesuai dengan prosedurnya. Namun, ada hal yang perlu dilakukan perbaikan. Salah satunya yaitu pada tahap pembekalan. Pada tahap pembekalan khususnya pada saat peserta melaksanakan magang, banyak diantara peserta yang kurang mengikuti dengan serius dan tekun. Ini akan berakibat kurangnya keterampilan peserta pada saat pelaksanaan Program Mahasiswa Wirausaha berjalan.

Hasil wawancara mengenai mekanisme Program Mahasiswa Wirausaha disimpulkan bahwa sudah berjalan sesuai dengan prosedurnya. Namun, lebih ditingkatkan pada sub indikator tahap pembekalan khususnya pada magang yang dilakukan mahasiswa. Magang yang dilakukan mahasiswa hendaknya dilaksanakan dengan serius dan tekun agar keterampilan yang didapat bertambah setelah magang dilakukan.

Hasil untuk indikator hambatan dalam Program Mahasiswa Wirausaha diperoleh rata-rata sebesar 0,71 dengan tingkat pencapaian sebesar 70,71\% dan termasuk ke dalam kategori cukup. Artinya hambatandalam Program Mahasiswa Wirausaha cukup dirasakan bagi peserta. Hambatan yang ditemui diantaranya masih banyak peserta yang belum bisa membagi waktunya antara perkuliahan dan usaha yang dikelolanya. Hambatan berikutnya yaitu kurang nya kerja sama antar peserta dalam satu kelompok yang mengakibatkan usaha mereka terkadang tidak berjalan dengan baik. Banyak juga diantara usaha peserta yang tidak sama dengan program studi yang sedang dijalani. Hal ini akan menyebabkan peserta kurang bisa mencari solusi ketika hambatan sedang dialaminya. Jadi, komponen proses pada Program Mahasiswa Wirausaha tergolong dalam kategori cukup kurang memuaskandan perlu dilakukan perbaikan di masa yang akan datang guna pelaksanaan Program Mahasiswa Wirausaha di Universitas Negeri Padang yang lebih baik.

Hasil wawancara mengenai hambatan dalam Program Mahasiswa Wirausaha dapat disimpulkan bahwa masih banyak peserta yang belum bisa membagi waktunya antara perkuliahan dan usaha yang dikelolanya. Hambatan berikutnya yaitu kurang nya kerja sama antara peserta dalam satu kelompok usaha mengakibatkan usaha mereka terkadang tidak dijalankan. Banyak juga diantara usaha peserta yang tidak sejalan dengan program studi yang sedang dijalani. Hal ini akan menyebabkan peserta kurang bisa mencari solusi ketika hambatan sedang dialaminya.

Hasil untuk indikator solusi diperoleh rata-rata sebesar 0,80 dengan tingkat pencapaian sebesar 80,30\% dan termasuk ke dalam kategori baik. Artinya solusi yang diberikan oleh universitas dalam meminimalisir permasalahan atau hambatan Program Mahasiswa Wirausaha sudah baik. Hal ini terlihat dari pihak universitas telah mengatur untuk satu kelompok dari berbeda program studi.

Hasil wawancara mengenai solusi dapat disimpulkan bahwa solusi untuk masalah manajemen waktu peserta yaitu dengan membuat jadwal antara perkuliahan dan jadwal kegiatan wirausaha nya, agar tidak mengganggu salah satu diantara kegiatan yang dilakukan. Solusi untuk kurang nya kerjasama antara sesama peserta di dalam kelompok yaitu mencari satu teman kelompok yang mamiliki pemikiran dan bersama ingin mengembangkan usaha yang dikelola. Solusi untuk usaha yang tidak sinkron dengan program studinya yaitu sebaiknya peserta mencari usaha dibidang yang sama dengan program studi yang sedang dijalankannya, agar peserta paham dengan usaha yang dikelola. Pihak universitas juga akan membuat workshop untuk peserta dimana 
pada kegiatan tersebut akan ada materi tentang permasalahan dan kekurangan peserta dalam satu bidang tertentu

Skor perolehan rata-rata dari ketiga indikator terkait komponen proses Program Mahasiswa Wirausaha diperoleh sebesar 0,77 dengan tingkat pencapaian 77,41\% dan termasuk ke dalam kategori cukup. Dengan demikian dapat disimpulkan bahwa komponen proses perlu diperbaiki untuk sub indikator tahap persiapan, tahap pembekalan dan tahap pelaksanaan guna meminimalisir hambatan di masa yang akan datang, dan perlu ditingkatkan dan dioptimalkan untukindikator solusi terhadap hambatan dalam Program Mahasiswa Wirausaha.

\section{Komponen Hasil}

Hasil untuk indikator tingkat ketercapaian diperoleh rata-rata sebesar 0,62 dengan tingkat pencapaian sebesar $61,62 \%$ dan termasuk ke dalam kategori kurang. Artinya tingkat ketercapaian/ hasil yang diberikan dalam Program Mahasiswa Wirausaha masih kurang. Hal ini terlihat dari banyaknya jumlah usaha yang terhenti.

Peserta memiliki minat berwirausaha dan motivasi berwirausaha yang tinggi namun kesiapannya dalam pelaksanaan wirausaha, softskill atau karakter wirausaha, dan pola pikir pencipta lapangan kerja yang belum optimal. Selain itu, peserta masih kurang menjalani dengan serius dan tekun pada tahap pembekalan khusunya magang padahal kegiatan ini untuk menambah keterampilannya. Hambatan lainnya yang membuat hasil kurang memuaskan yaitu masih banyak peserta yang belum bisa membagi waktu antara perkuliahan dan usaha yang dikelolanya. Kurang nya kerja sama antar peserta dalam satu kelompok usaha juga mengakibatkan usaha mereka terkadang tidak dijalankan dan menjadi hambatan. Banyak juga diantara usaha peserta yang tidak sejalan dengan program studi yang sedang dijalani. Hal ini akan menyebabkan peserta kurang bisa mencari solusi ketika hambatan sedang dialaminya.

Hasil wawancara mengenai tingkat ketercapaian/ hasil dapat disimpulkan bahwa masih banyak usaha yang telah jalan namun berhenti dan tidak dijalankan untuk seterusnya. Namun dampak positifnya juga dirasakan yaitu adanya usaha dari peserta yang masih berjalan menjadikan mereka bisa mendapatkan penghasilan untuk memenuhi kebutuhannya. Dampak positif lainnya yang dirasakan oleh peserta yaitu menambah sumber belajar dan pengetahuannya tentang wirausaha.

Berdasarkan data kuantitatif dan data kualitatif tersebut dapat disimpulkan bahwa hasil dalam Program Mahasiswa Wirausaha ini tidak terlaksana dengan baik. Pihak universitas dan tim pelaksana harus lebih meningkatkan dan mengoptimalkan pelaksanaan Program Mahasiswa Wirausaha, dan memperbaiki komponen-komponen yang perlu diperbaiki seperti tujuan, sumber daya manusia (peserta), mekanisme dan sebagainya.

Sudjana (2008:56) menyatakan bahwa evaluasi hasil mengukur dan menginterpretasikan pencapaian program selama pelaksanaan program dan pada akhir program yaitu berupa keluaran yang dihasilkan. Evaluasi hasil Program Mahasiswa WirausahaUniversitas Negeri Padang dapat dirasakan langsung dari peserta yang usahanya masih berjalan seperti mendapatkan dari pengetahuan dalam berwirausaha hingga mendapatkan pendapatan tambahan. Oleh karena itu, agar pelaksanaannya lebih optimal dilakukan perbaikan dari semua unsur, yaitu konteks, masukan, dan proses.

\section{E. Penutup}

Berdasarkan hasil penelitian evaluasi Program Mahasiswa Wirausaha di Universitas Negeri Padang, maka dapat diperoleh kesimpulan sebagai berikut. 
Komponen konteks pada Program Mahasiswa Wirausaha tergolong pada kategori cukupdan perlu diperbaiki supaya implementasi tujuan program dapat berjalan dengan sangat baik untuk ke depannya.Komponen masukan pada Program Mahasiswa Wirausaha tergolong pada kategori cukup dan perlu dilakukan peningkatan di masa yang akan datang.

Komponen proses pada Program Mahasiswa Wirausaha tergolong pada kategori cukupdan perlu diperbaiki guna pelaksanaan Program Mahasiswa Wirausaha yang lebih baik.Komponen hasil pada Program Mahasiswa Wirausaha tergolong pada kategori kurang artinyaProgram Mahasiswa Wirausaha Universitas Negeri Padang tidak terlaksana dengan maksimal (kurang efektif) karena hanya 6 kelompok usaha yang masih berjalan dari 33 kelompok yang mendapatkan dana bantuan modal peserta Program Mahasiswa Wirausaha tahun 2016.

\section{Daftar Pustaka}

[1] Arikunto, Suharsimi \& Jabar, Cepi Syafruddin Abdul. (2010). Evaluasi Program Pendidikan. Jakarta: Bumi Aksara.

[2] Direktorat Jenderal Pendidikan Tinggi. 2015. Buku Pedoman Program Mahasiswa Wirausaha (PMW). Jakarta : Dikti.

[3] Sukardi. (2011). Evaluasi Pendidikan, Prinsip \&Operasionalnya. Jakarta: Bumi Aksara.

[4] Wirawan. 2011. Evaluasi Teori, Model, Standar, Aplikasi, dan Profesi. Depok: Rajawali Press, PT Rajagrafindo Persada. 